\title{
TROPHOPOD, A COMMONLY OVERLOOKED STORAGE STRUCTURE OF POTENTIAL SYSTEMATIC VALUE IN FERNS
}

\author{
W. H. Wagner, Jr. and D. M. Johnson'
}

\section{Summary}

A food storage organ, the trophopod, is described from a number of North American ferns. It consists of the enlarged and modified leaf base filled with starch storage tissue.

In comparison with the systematics of most groups of seed plants that of the ferns is hampered by paucity of comparative characters. For this reason pteridologists are on constant lookout for new sources of comparative data. Novel sources of variables are especially timely today when taxonomic activity in the study of ferns is at the highest level in history, and revisions are being made at all levels from the variety and species to the family and order.

Assorted attributes of leaf bases in ferns have been used in many groups. The length of the petiole or stipe in relation to the blade is of major value in Elaphoglossum, for example. The presence of stipules in Marattiales, as well as the stipule-like expansions of the petiole base in Osmundales, are well known diagnostic characters for these groups. Delicate, lacelike aphlebiae, which are modified pinnae or outgrowths on the petiole are useful taxonomic characters in certain Cyatheaceae and Hymenophyllaceae. The Ophioglossales display well developed leaf sheaths, and the question of whether they are open or closed aids in defining the subgenera of Botrychium. Phyllopodia, basal segments of the petioles from which the fronds dehisce, are scattered among epiphytes in such genera as Elaphoglossum and Olean$d r a$; they probably constitute homoplastic adaptations of unrelated taxa. Numerous fern groups show abscission of fronds, whether from phyllopodia or directly off the rhizome, including genera as disparate as Polypodium and Woodsia. The persistence of leaf bases long after their distal parts have rotted away is familiar as a protective device in a variety of ferns. The more specialized so-called "leaf armor" or "leaf-base armor," found in Osmundaceae, is made up of compact masses of leaf bases, these usually sclerified and well adapted for covering the delicate rhizome within.

We briefly describe here a type of structure involving the petiole base that has heretofore been largely ignored or overlooked in ferns, and which we believe has potential as a source of new systematic data. It is most evident in fresh material, however, so that examination of living plants is necessary. The formation of the structure involves the enlargement, modification, and retention of the leaf base to accommodate masses of starch storage tissue.

Our interest in this structure began in our study of the natural history of the eastern North American fern, Asplenium platyneuron (L.) B.S.P. (Aspleniaceae). Food storage in this species, we found, is substantially foliar rather than cauline (Wagner and Johnson, 1981, fig. 3). The petiole bases remain an estimated seven years. At this age, the remainder of the petioles and blades have long since decayed, and to the touch the storage basal region of the petiole feels hard and thickened. The firm yellowish storage tissue within contains a multitude of starch grains, and the surfaces of the persistent bases are shiny black to maroon in color and heavily sclerotized.

Department of Botany and Herbarium, University of Michigan, Ann Arbor, MI 48109, U.S.A. 
For this structure we propose the term trophopod (i.e., trophopodium or feeder petiole), and define it as a petiole base that is specialized to accumulate food and to persist as a storage organ long after the frond to which it belonged has withered and decayed away. In our survey of a variety of temperate ferns over the past two years we have observed trophopods that range from approximately 1.5 to $3 \mathrm{~cm}$ in length and 3 to $10 \mathrm{~mm}$ in width. The surface layers are tough and commonly sclerified, presumably to insure protection of the starchy tissues within from predation or decomposition. In total volume more of the storage for the plant as a whole may be accomplished by the trophopods than by the rhizome.

Thus far our field observations, which are continuing at present, show that trophopods are widespread among ferns, including many common and familiar species. They tend to collapse and lose their distinctive appearance when they are pressed and dried, as in herbarium specimens. Good examples of trophopods in North American ferns are to be seen in such genera as Onoclea, Matteuccia, Athyrium, and Dryopteris. They seem to be absent in certain large groups of ferns (e.g., Adiantaceae and Thelypteridaceae). Ferns that grow obligately on rocks have them rarely or not at all. The same appears to be true of epiphytic ferns, but we have not had sufficient opportunity to study this phenomenon in the tropics to be sure. In evergreen or wintergreen ferns which possess them, the trophopods remain for long periods after the upper petiole and blade have disappeared, just as they do in deciduous ferns.

The example (cited above) of Asplenium platyneuron is especially interesting because all of its allies in eastern North America lack trophopods. All of the other aspleniums, however, are exclusively rock-inhabiting ferns, whereas $A$. platyneuron is more commonly terrestrial than saxicolous. In North American Dryopteris, the species, with one exception, are terrestrial. The single obligately rock-inhabiting species, $D$. fragrans, lacks trophopods, but all of the others possess them. Thus our preliminary studies indicate that there are ecological, as well as taxonomic, correlations.

The attention of taxonomists, field botanists, ecologists, and physiologists is called to these interesting storage organs. We suggest that plant collectors note at the time of collection whether or not trophopods are produced in a given species, and that that information be preserved on herbarium specimen labels.

\section{Literature Cited}

Wagner, W. H., Jr. and David M. Johnson. 1981. Natural history of the Ebony Spleenwort, Asplenium platyneuron (Aspleniaceae), in the Great Lakes area. Canadian Field-Naturalist 95: 156-166. 